\title{
Law Enforcement against Marine Pollution Foreign Ships in Indonesia
}

\author{
Indien Winarwati ${ }^{1}$ \\ \{indienwinarwati@gmail.com ${ }^{1}$ \} \\ Faculty of Law, University of Trunojoyo Madura, Indonesia ${ }^{1}$
}

\begin{abstract}
Marine pollution is mainly caused by oil spills from ship operations and offshore drilling. Indonesian waters have the potential to be polluted by ships due to busy shipping activities. This paper tries to answer the regulation of marine pollution prevention by foreign ships and law enforcement carried out by Indonesia. This research is a normative legal research which examines juridical aspects with a statutory approach. It addresses issues under laws and regulations relating to the prevention of pollution at sea by ships. The results showed that the regulation of marine pollution prevention by ships includes Law Number 17 of 2008 concerning Shipping, Government Regulation Number 19 of 1999 concerning Control of Marine Pollution and / or Destruction, Government Regulation Number 51 of 2002 concerning Shipping and Regulation of the Minister of Transportation Number. KM 4 of 2005 concerning Prevention of Pollution by Ships. Indonesia enforces laws relating to the prevention of marine pollution by foreign ships based on the provisions of Article 1 paragraph (1) and Article 4 paragraph (1) MARPOL.
\end{abstract}

Keywords:Law enforcement, pollution, sea, foreign ships, Indonesia.

\section{Introduction}

As Indonesia's property the sea and the habitat should be maintained for sustainability. Unfortunately, however, marine pollution in Indonesia's territorial waters is very high, especially those caused by oil spills.. Marine pollution is among the environmental problems we face today and is often caused by human activities. Most of marine pollution are caused by humans either directly or indirectly.

Pollution is defined as the entry or introduction of living things, substances, energy, and/or other components into the marine environment by human activities, leading to a decrease in quality to a certain level causing the marine environment no longer conforming to the quality standards and/or functions.. The main source of marine pollution usually is oil spills originating from ship operations, offshore drilling (exploration) or ship accidents. Shiporiginated marine pollution is classified into four types: ship operations, dumping, seabed activities and onshore activities.

Indonesian waters are potentially polluted by ships due to busy shipping activities. One example is the Malacca Strait, which is the world's busiest ship crossing. With 2.33 billion ship stopover at the Port of Singapore, waters directly adjacent to the Malacca Strait are potentially polluted [1]. These incidents include the Montara case which has lasted for 10 
years, the oil spill in Balikpapan in 2018, and the collision of MV Caledonia Sky and reefs in Raja Ampat. Those incidents polluted and/or damaged the marine and coastal ecosystems [2]. In addition, in 2018 an incident of oil leakage occurred off the coast of Balikpapan, Indonesia. The incident was caused by the rupture of the pipeline leading to Pertamina's refinery due to scratching by the ship's anchor. The resulting explosion when an oil leak was spattered by fire killed five people while they were in Balikpapan Bay. The Balikpapan District Court sentenced Zong Deyi, the captain of MV Ever Judger, to 10 years in prison. In addition, the captain of Chinese nationality was also fined IDR 15 billion with a subsidiary sentence of 1 year in prison. However, Zong Deyi rejected the verdict since it was perceived as too heavy. Statements of the problems are How is the arrangement of prevention of marine pollution by foreign ships? Has the law enforcement committed by Indonesia with regard to the prevention of marine pollution been compliant with the provisions of the International Environmental Law?

\section{Literature Review}

\subsection{Causes of Marine Pollution}

Activities on land and air are the biggest source of marine pollution, accounting for about three-quarters of marine pollution from land pollution entering the oceans. Apart from that waste originating from land activities such as landfills near the beach or garbage carried by waterways and rivers in urban areas, besides that, dumping and disposal activities from marine vehicles also contribute to the amount of garbage in the ocean [3].

Indonesia is a maritime country, its sea area is larger than its land area. The beauty and richness of Indonesia's sea is so charming, but the occurrence of environmental pollution which often occurs slowly destroying the marine ecosystem. The sea is an important part of life. For humans, the sea can be a source of livelihood to make life necessities. Fishermen can benefit from fishing in the sea. Because of the importance of the sea for many parties, all parties must think about how to overcome it in the event of marine pollution

Some of the factors that cause marine pollution, among others, are waste. Factory waste that is directly flowed into the sea will cause pollution in sea water. Industrial waste contains various hazardous metals such as mercury, arsenic, lead, and so on. This is what ultimately causes pollution in the sea. As a result, many members of the marine ecosystem will die.

Marine pollution can also occur due to offshore mining activities. When offshore mining is carried out, there will be waste generated. Because it is in the middle of the sea, the only place where the waste is dumped is in the sea. Due to an oil spill, the condition of sea water will change. Water and oil have different characteristics and do not mix. In addition, waste oil also contains dangerous substances that are quite easy to kill fish ecosystems in the sea. With the existence of marine pollution due to mining and industrial waste, it has disrupted the ecosystem of marine resources, for example the death of fish and the destruction of coral reefs [4].

Furthermore, sources of marine pollution originating from ships are classified into four types, namely ship operation activities and disposal (dumping), activities on the seabed and activities on land [2].

Another cause of marine pollution is garbage. Garbage carried by river currents can end up in the sea. If every day the volume of waste that pollutes the sea increases, the life of marine life will be disturbed. Globally, the percentage of waste that pollutes the sea is plastic waste which accounts for $60-80 \%$ of all marine debris, while in some places the presentation reaches $90-95 \%$ of all marine debris. There is no strong scientific data regarding the origin of this waste, but it is estimated that $80 \%$ comes from land and $20 \%$ comes from ships. Fish 
exploitation is one of the factors that can cause marine pollution problems. Fishermen who carry out fishing on a large scale using explosives or other dangerous materials will disturb the regeneration of marine fish.

\subsection{State Obligation to Prevent Marine Pollution}

The 1982 United Nations Convention On The Law Of The Sea (UNCLOS) states that every country has the right to sail under its flag on the high seas, but that country must also effectively exercise jurisdiction and oversight in administrative, technical and social fields. on ships flying its flag More generally, each country is obliged to protect and conserve the marine environment from the dangers of pollution, but countries are not fully to determine its national provisions relating to the matter environmental protection from the threat of pollution.

UNCLOS completely regulates the protection and preservation of the marine environment. Article 192 states that every State has the obligation to protect and preserve the marine environment. Article 193 outlines an important principle in the utilization of resources in the marine environment, namely the principle which states that every State has the sovereign right to exploit its natural resources in accordance with their environmental policies and in accordance with its obligations to protect and conserve the marine environment.

States parties to the 1982 Convention on the Law of the Sea have an obligation to comply with all provisions of the Convention regarding the protection and preservation of the marine environment, namely as follows:

1. Obligation to make laws and regulations on the protection and preservation of the marine environment that comprehensively regulate including the prevention of pollution of the marine environment from various sources of pollution, such as pollution from land, ships, dumping, and others. The laws and regulations include law enforcement, namely the court process

2. The obligation to make efforts to prevent, reduce and control pollution of the marine environment,

3. The obligation to undertake regional and global cooperation, if regional cooperation means cooperation at the level of ASEAN member countries, and meaningful global cooperation with other countries that involves countries outside ASEAN because now the problem of marine environmental pollution is a global problem, so that the handling must be global as well.

4. States must have rules and equipment as part of the contingency plan

5. The statutory regulations are accompanied by a process of accountability mechanisms and liability compensation for parties who have suffered losses due to marine pollution.

In carrying out the obligation to protect and conserve the marine environment, each State is required to cooperate both regionally and globally..This regional and global cooperation can be in the form of cooperation in notification of marine pollution, joint handling of the dangers of marine pollution, forming contingency plans against pollution, studies, research, exchange of information and data and making scientific criteria. to regulate procedures and practices for the prevention, reduction and control of pollution of the marine environment In addition, each State oblige to make legislation regulating the prevention and control of marine pollution from various pollution sources, such as land-based sources, pollution from seabed activities within its national jurisdiction, pollution from activities in the Area, pollution from dumping, pollution from ships and pollution from the air [5].

\section{Methods}


This research is a type of juridical normative research, which is a scientific procedure to find the truth based on literature and secondary legal materials. This research approach uses the statute approach method. The legal materials used are primary and secondary legal materials. These legal materials are analyzed using descriptive-analysis techniques, namely by linking to legal principles based on legal theories related to existing legal problems, namely law enforcement against pollution by ship.

\section{Result and Discussion}

\subsection{Arrangement of the Prevention of Marine Pollution by Ships}

Indonesia has issued several laws and regulations concerning the protection of the marine environment and the arrangement of the prevention of marine pollution, including:

Law No. 32 of 2009 on Environmental Protection and Management which in general sets out efforts to preserve the function of the environment and to prevent pollution and/or damage to the environment that include planning, utilization, control, maintenance, supervision, and enforcement, constitutes a legal umbrella of the environmental law to produce other, more specific laws.

Law No. 17 of 2008 on Shipping. The arrangement of the prohibition of marine or aquatic pollution originating from disposal activities of waste and other hazardous materials is set out in Chapter XII regarding Maritime Environmental Protection of Articles 226 to 230. Article 226 paragraph (2) states that The protection of the maritime environment as referred shall be undertaken by preventing and overcoming pollution from ship operations. Furthermore, Article 227 states that each and every crew member is obliged to prevent and cope with environmental pollution originating from the ship. Article 228 paragraph (2) state that Ships of a certain type and size that are operated shall be equipped with a pattern for coping with ship-originated oil pollution approved by the Government.. Article 229 paragraph (1) states that each and every ship is prohibited from disposing of waste, ballast water, sewage, garbage, and hazardous and toxic chemicals into the waters. Article 230 paragraph (1) stipulates that each Skipper or person in charge of other activity units in the waters shall be responsible for coping with pollution from ships and/or activities.

Government Regulation Number 19 of 1999 concerning Marine Pollution and/or Destruction Control. Article 9 stipulates that each and every person or person in charge of a business and/or activity is prohibited from performing acts that can lead to marine pollution. Furthermore, Article 10 paragraph (1) stipulates that each and every person in charge of a business and/or activity that may cause marine pollution shall prevent marine pollution. Article 15 paragraph (1) states each and every person or person in charge of a business and/or activity that causes marine pollution and/or destruction shall prevent marine pollution and/or destruction caused by its activities. Article 24 (1) states that every person or person in charge of a business and/or activity that causes marine pollution and/or destruction is obliged to bear the cost of overcoming marine pollution and/or destruction as well as the cost of restoring it.

Government Regulation Number 51 of 2002 on Vessels. The Government Regulation also sets out prevention of marine pollution from ships. Article 126 paragraph (1) sets out that companies that operate vessels of a certain type and size shall have a certificate of ship operation safety management and the prevention of ship-originated pollution.

Minister of Transportation Regulation Number KM 4 of 2005 concerning Prevention of Pollution Originated from Ships. Article 2 set out the provisions of the prohibition for every vessel (especially oil-loading tankers and the provision does not apply to warships as referred 
to Article 13) from disposing of oil or oily waste in Indonesian waters and the Indonesian Exclusive Economic Zone. Furthermore, Article 20 sets out that the owner or operator of the ship shall be responsible for the pollution that resulted from his ship at the nominal amount of guaranteed compensation funds for pollution accounted for. Thus, the arrangements for the prevention of marine pollution in Indonesia are found in several laws and the implementation rules.

\subsection{Law Enforcement Undertaken by Indonesia against Marine Pollution by Foreign Ships}

Indonesia is the largest archipelago in the world and one important member of the IMO (International Maritime Organization). For this reason, Indonesia has ratified the IMOproduced International Convention on the Prevention of Pollution from Ships in 1973 and its protocol in 1978, namely the International Convention for the Prevention of Pollution from Ships 73/78 known as Maritime Pollution (MARPOL). It is stated in the considerations of the Presidential Decree "that for the purpose of preserving marine environment from pollution originated from the operation of ships [6].

MARPOL contains obligations for each member country to comply with and implement the provisions in order to protect the marine environment from pollution. The duties and authorities of MARPOL member countries as referred to in the provisions of the International Law of the Sea (UNCLOS).

In connection with the provisions of the prevention of pollution by ships Article 1 paragraph (1) of MARPOL states that: The Parties to the Convention undertake to give effect to the provisions of the present Convention and those Annexes thereto by which they are bound, in order to prevent the pollution of the marine environment by the discharge of harmful substances or effluents containing such substances in contravention of the present Convention. This means that the States to the convention have an obligation to apply the precautionary principle of preventing pollution, especially oil which can pollute the marine environment. Furthermore, provisions regarding violations of this convention are regulated in Article 4 paragraph (1) states that::Any violation of the requirements of the present Convention shall be prohibited and sanctions shall be established therefor under the law of the Administration of the ship concerned wherever the violation occurs. If the Administration is informed of such a violation and is satisfied that sufficient evidence is available to enable proceedings to be brought in respect of the alleged violation, it shall cause such proceedings to be taken as soon as possible, in accordance with its law.

Law enforcement undertaken by Indonesia on the prevention of marine pollution by foreign vessels is regulated in several laws and the implementation rules, including Law No. 17 of 2008 concerning Shipping. Article 226 Paragraph (1) of the Law states that maritime environmental protection is undertaken by the Government and paragraph (2) states that maritime environmental protection as referred to in paragraph (1) shall be undertaken by preventing and controlling of pollution from ship operations. Article of 227 states that each and every crew member is obliged to prevent and overcome environmental pollution originating from the ship. Article 230 paragraph (1) states that each captain or person in charge of other activity units in the waters is responsible for overcoming pollution originating from the ship and/or its activities. Furthermore, Government Regulation Number 19 of 1999 concerning Control of Marine Pollution and/or Destruction and Article 9 states that every person or person in charge of a business and/or activity is prohibited from engaging in actions that can cause marine pollution. Article 10 paragraph (1) states that each and every person in charge of a business and/or activity that can cause marine pollution is obliged to prevent 
marine pollution. Article 24 paragraph (1) states that each and every person or person in charge of a business and/or activity that causes marine pollution and/or destruction is obliged to bear the cost of overcoming marine pollution and/or destruction and the cost of restoring it. Furthermore, Article 20 of Minister of Transportation Regulation No. KM 4 of 2005 concerning Prevention of Pollution from Ships states that owner or operator of the ship shall be responsible for the pollution that resulted from his ship at the nominal amount of guaranteed compensation funds for pollution accounted for.

On the basis of several regulations concerning the prevention of marine pollution, a conclusion can be drawn that the provisions concerning the prevention of marine pollution made by Indonesia are in accordance with the provisions contained in MARPOL, that the participating States are obliged to apply the principle of preventing pollution that can pollute the marine environment. Thus, law enforcement undertaken by Indonesia against violations of the prevention of marine pollution by foreign ships does not contradict the provisions of MARPOL.

\section{Conclusions}

The regulations for preventing marine pollution by ships are contained in several laws and the implementation regulations which include Law Number 32 of 2009 concerning Environmental Protection and Management which regulates in general terms of efforts to conserve environmental functions and prevent environmental pollution and/or damage. Law Number 17 of 2008 concerning Shipping regulates the prohibition of marine pollution or waters originating from activities of disposing of waste and other hazardous materials. Furthermore, Government Regulation Number 19 of 1999 concerning Control of Marine Pollution and/or Destruction and Government Regulation Number 51 of 2002 concerning Shipping regulate the prevention of marine pollution from ships. Furthermore, Minister of Transportation Regulation Number KM 4 of 2005 concerning Prevention of Pollution from Ships regulates the prohibition for each ship to discharge oil or oily waste in Indonesian waters and the Indonesian Exclusive Economic Zone.

Law enforcement undertaken by Indonesia with regard to the prevention of marine pollution by foreign vessels is in accordance with the provisions in Article 1 paragraph (1) and 4 paragraph (1) of MARPOL which state that the State will apply these conventions to prevent pollution of the marine environment from disposal of hazardous waste and substances and the State may not violate the provisions of MARPOL. Thus, law enforcement undertaken by Indonesia under laws made by Indonesia does not contradict the provisions of International Environmental Law.

\section{References}

[1] E. S. Puspoayu, A. R. Hakim, and H. Selsiana, "Judicial Review of Oil Pollution Responsibility in the Balikpapan Bay Area," Ius Quia Iustum Law J., vol. 25, no. 3, 2018.

[2] Azaria and D. Prawidya, "Perlindungan Lingkungan Laut Samudra Pasifik Dari Gugusan Sampah Plastik Berdasarkan Hukum Lingkungan Internasional," Kumpul. J. Mhs. Fak. Huk., vol. 0, no. 0, pp. 1-18, 2014.

[3] Rizky W. Santosa, "Dampak Pencemaran Lingkungan Laut Oleh Perusahaan Pertambangan 
Terhadap Nelayan Tradisional,” Lex Adm., vol. 1, no. 2, pp. 65-78, 2013.

[4] I. Gusmayanti, "PENERAPAN PENGATURAN PEMBUANGAN LIMBAH MINYAK KE LAUT OLEH KAPAL TANKER DILIHAT DARI PERSPEKTIF HUKUM LINGKUNGAN DI INDONESIA,” J. Huk. Lingkung. Indones., vol. 1, no. 1, 2014, [Online]. Available: https://jhli.icel.or.id/index.php/jhli/article/view/8/9.

[5] L. S. Sakti, D. G. S. Mangku, and N. P. R. Yuliartini, "Tanggung Jawab Negara Atas Pencemaran Lingkungan Laut Akibat Tumpahan Minyak di Perbatasan Laut antara Indonesia dan Singapura Menurut Hukum Laut Internasional," J. Komunitas Yust., vol. 2, no. 1, 2019, [Online]. Available: https://ejournal.undiksha.ac.id/index.php/jatayu/issue/archive.

[6] J. Malisson, "Kajian Pencemaran Laut Dari Kapal Dalam Rangka Penerapan Pp Nomor 21 Tahun 2010 Tentang Perlindungan Lingkungan Laut," J. Teknol., vol. 16, no. 2, pp. 2114-2121, 2017. 